\title{
Farmers Awareness And Perception Towards Crop Insurance
}

\section{M.Sukanya}

ABSTRACT--- Agriculture production is not guaranteed due to natural calamities like floods, droughts, cyclones, and, etc. The risk-bearing capacity of small farmers is limited. This study investigates the awareness and perception of farmers towards crop insurance in Karimnagar district of Telangana state.

Thereby to minimize the risk and uncertainty in agriculture production, the government of India and also the state governments have launched several schemes such as National agriculture scheme and weather based scheme insurance scheme. Questionnaire designed to collect the data and projects the perception of farmers under tenancy are not ready to take the crop insurance as they are already paying the lease charges some of them are not ready to take up crop insurance due to high rate of premiums, it is observed that the farmers having the fewer acres of land have a thought that crop insurance does not fetch them. Concluding remarks of the article are insurance agencies should take a step forward to educate the farmers about crop insurance benefits and its uses, and also by reducing the premium rates \& claim settlement procedures.

Keywords: Crop Insurance, Agriculture production, Perception of farmers, Insurance Agencies and Government schemes.

\section{INTRODUCTION}

Agriculture is a back bone of the Indian economy. $60 \%$ $70 \%$ of the population depends on this sector; but produce from this sector is facing many types of risks and uncertainty because of many factors which include Irrigation.

Agriculture is the process of producing food, feed, fiber and many other desired products by the cultivation of certain plants and the raising of domesticated animals.

\section{REVIEW OF LITERATURE}

1. S.B. Goudappa, B.S. Reddy and S.M. Chandrasekhar, This study reveals that the most of the respondents in the Karnataka state are not aware of the extent of coverage of premium rates and procedure and methods of loss determination and compensation worked out by agriculture insurance companies. So, the government of Karnataka may conduct an awareness campaign to create awareness among the farmers about the crop insurance schemes and procedure of claims of settlement. by doing this, we can improve the lifestyle of the farmers.(goudappa, 2012)

2. J. Sundar, Dr. Lalitha Ramakrishnan, In this article author mainly focus on the awareness level and perception towards the crop insurance among the farmers. He collected the data through questionnaire method with a

Revised Manuscript Received on on August 14, 2019.

Dr. M.Sukanya, Associate Professor \& HOD, SMS, SNIST, Hyderabad, Telangana, India. (Email: dr.sukanyamadasu@gmail.com.) sample of 140 respondents in Puducherry district, India. From the study, author conclude that most of the respondents are not aware of crop insurance existence and most of the farmers are thought that crop insurance does not suit to small farmers.. (j.sundar, 2013)

3. Geetha, This article tells about awareness, purchase benefits and satisfaction towards the crop insurance. This study tells that more than $25 \%$ of respondents were not aware of crop insurance schemes and more than $15 \%$ of respondents felt that there is no need for insurance due to various reasons like education level of the farmers and delay in the payment of compensation.(Ramakrishnan, 2015)

4. Amrita Ashok Kulkarni, This study tells about the awareness of the farmers in the selected area about crop insurance. This study tells that the farmers in the droughtprone area are less aware of crop insurance. Only $1.51 \%$ of farmers from maantelhi and $2.58 \%$ farmers out of the overall population are aware of insurance, and they are taking advantage of this scheme. (Kulkarni, 2017)

\section{RESEARCH METHODOLOGY:}

\subsection{Need for the study:}

From the past study it had been found that the farmer's perceive that crop insurance suits only for large size farmers and high income farmers.

So the service providers have to look on to new product which offers effective focus on financial economic losses in affordable premium to small and marginal farmers.

This study attempted to assess the awareness level of farmers towards crop insurance in Karimnagar district with a sample of 60 respondents through a structured questionnaire.

\section{2: Objectives of the study}

1. To study the Awareness of crop insurance among the farmers.

2. To study the Perception of farmers towards crop insurance.

3. To study the Willingness to take the crop insurance policy by farmers.

\section{3: Scope of the study:}

The study is confined to Karimnagar district at Telangana state addressing farmers who have up to 100 acres of land.

Sample is drawn from the population is infinite hence non-probability sample of convenience sampling method has been used. 


\section{4: Methods of data collection}

Primary source of data: Primary data is collected through a structured questionnaire distributed among the respondents.

\section{5: Hypothesis of the study:}

H1 There is a significant difference between educational level and awareness level of crop insurance.

H2 There is a significant difference between income level and awareness level of crop insurance.

H3 There is a significant difference between the willingness of landlord and crop insurance policy.

\subsection{Limitations of the study}

The data provided by the respondents is also genuine as they could clearly understand the need of their lives which requires improvement.

\section{DISCUSSION OF ANALYSIS \& RESULTS}

The present study examined the farmer's awareness and willingness to purchase crop insurance. The following are the objectives tested and examined with the chi-square test.

Educational level and awareness level of crop insurance.

Table 1.1 Chi-square tests

\begin{tabular}{|c|c|c|c|}
\hline & value & df & $\begin{array}{c}\text { Asymp. } \\
\text { Sig. } \\
\text { (2-sided) }\end{array}$ \\
\hline $\begin{array}{c}\text { Pearson } \\
\text { chi- } \\
\text { square }\end{array}$ & 4.999 & 3 & .172 \\
\hline
\end{tabular}

From the above table 1.1 shows that there is no significance difference between the educational qualification and awareness of crop insurance policy.

Chi-square test proves that there no significant difference between educational background and awareness level of crop insurance. Hence, Null hypothesis is accepted.

Income level and awareness level of crop Insurance Table: 2 Chi-square tests

\begin{tabular}{|l|l|l|l|}
\hline & value & df & $\begin{array}{l}\text { Asymp. } \\
\text { Sig. } \\
\text { (2-sided) }\end{array}$ \\
\hline $\begin{array}{l}\text { Pearson } \\
\text { chi- } \\
\text { square }\end{array}$ & 10.731 & 3 & .013 \\
\hline
\end{tabular}

The above table 2 . Indicates the relationship between income level and awareness level of crop Insurance among the farmers. Based on the observations from the table, there is significant difference between the income level of a farmer and awareness of crop insurance. Chi-square test proves $\mathrm{p}$ value is less the table value. So, Null hypothesis is rejected.
Willingness to take crop insurance Table: 3Chi-square tests

\begin{tabular}{|l|l|l|l|}
\hline & value & df & $\begin{array}{l}\text { Asymp. } \\
\text { Sig. } \\
(2- \\
\text { sided })\end{array}$ \\
\hline $\begin{array}{l}\text { Pearson } \\
\text { chi- } \\
\text { square }\end{array}$ & 3.547 & 3 & .315 \\
\hline
\end{tabular}

The above table 3 shows the relationship between the two variables that are own land and. There is no significant difference between the two variables of the landlord or tenant of the land, both are interested to take insurance but, at the same time they felt premium charged are very high hence, Null hypothesis is accepted.

\section{FINDINGS AND CONCLUSION:}

1. From the above observations, it was found that most of the farmers are not aware of "crop insurance existence."

2. From the study, it was found that there are two types of farmers, who are the tenant of the land and owner of the land which means, though the one who owns the land knows crop insurance.

3. However, they are not ready to opt for crop insurance due to high premium rates, and claim settlement procedure is too long.

4. Moreover, the other one who is a tenant of the land is not ready to take the crop insurance as they are already paying the lease charges, which means though they are aware of the crop insurance.

5. From the study, it is observed that the farmers who are having fewer acres of land have a thought that crop insurance does not fetch them anything as they farm less amount of crop.

\section{CONCLUSION:}

From the above findings, I suggest that crop insurance is a must for both small farmers and large-scale farmers.

As crop insurance protects the farmers from the uncertainty of risk in farming like natural calamities (floods, droughts, cyclones, and earth quakes, etc.).

That crop insurance is mandatory for every type of farmer; Government should take the initiative to give subsidies for small scale farmers and large-scale farmers as a basis of proportion to their income levels.

I also suggest that insurance agencies should take a step forward to educate the farmers about crop insurance benefits and its uses, and also by reducing the premium rates \& claim settlement procedures. Even than various schemes available for farmers, they are giving only lip service.

\section{REFERENCES}

1. Abbeam, G. D. (2017). Willingness to pay for farm insurance . Jpurnal of social science for policy 
implicationas, 163-183.

2. Abdullahi. (2016). The peception of rural farmers. International journal of agricultural policy and research, $17-21$.

3. Akthar, R. (2017). Willingnes to pay for crop insurance to adopt flood risky by farmers in malaysia. Interantional journal of economics and financial issues, 1-9.

4. Duhan, A. (2017). Farmers perception towards the crop insurance. International journal of research, 1-6.

5. Falola, A. (2012). Willingness to take crop insuramnce by cocoa farmers. International journal of food and agricultural economics, 97-107.

6. Ghanzafar, S. (2015). Farmers willingness to pay for crop imsurance. Journal of business, economics and finance, 166-179.

7. Goudappa, S. (2012). Farmers perception and awareness about crop insurance in karnataka. 218-222.

8. J.sundar. (2013). A study on farmers, perception and willingness to join and pay for crop insurance. International journal of business and management invention, 48-52.

9. Kulkarni, A. A. (2017). Awareness of crop insurance in farmers. Satara: research front.

10. Pandaraiah, M. (2015). Crop insurance: farmers perception and awareness. International journal of economic and business, 123-131.

11. Priya, T. M. (2014). Farmers perception and awareness about crop insurance. International journal of marketing research review, 15-22.

12. Ramakrishnan, I. (2015). A study on awareness and purchase benefits towards crop insurance. Pacific business review international, 38-45.

13. Thirumoorthy, D. R. (2017). International journal of multidisciplinary research. A study on farmers awareness and their perception in namaakal district, 104-108 